\title{
A arte de narrar de Ranchinho e de Efigênia Rolim
}

\begin{abstract}
Resumo: O presente artigo é o resultado parcial do Abstract: The present article is the partial result of the projeto de pesquisa "Infames, casos de singularidade research "Infamous, Cases of Historical Singularity". histórica". Tendo em vista a ampliação do campo de Having in mind the amplification of the investigation investigação dos "estudos culturais" e sua ênfase mais area of the "cultural studies" and its emphasis more in no sentido de cultura do que de letra do léxico littera, the sense of culture than in the lexicon littera, we discorremos sobre a arte de narrar de dois artistas: discourse about the art of narrate from two artists: Ranchinho e Efigênia Rolim. Ranchinho conta histórias Ranchinho and Efigênia Ramos Rolim. Ranchinho tells sobre a cultura caipira com a habilidade narrativa de stories about the country culture with the narrative seu pincel e Efigênia cria, com os restos deixados pelo ability of his paint brush, while Efigênia creates stories homem no mundo, histórias e objetos; ela é uma and objects; she is a ragman narrator. Both of them narradora trapeira. Ambos possuem muita coisa em have many things in common: the humble roots, their comum: a origem humilde, suas histórias de vida, entre life stories, among other things. They prove that the outras coisas, e são a prova de que o narrador traditional narrator is not dead, only transformed and tradicional não morreu, transformou-se e vive em uma living in an ambiguous situation, between the situação ambígua, ou seja, entre a experiência e a experienced and the lived, between being the vivência, entre ser o guardião da tradição e o seu tradition's guardian and its transformer.

transformador.
\end{abstract}

Palavras-chave: narrador; tradição oral e artes plásticas; memória; cultura caipira; performance
Keywords: narrator; oral tradition and plastic arts; memory; country culture; performance

\section{A “utopia retrospectiva” de Ranchinho}

A obra de Sebastião Theodoro Paulino da Silva (1923-2003), mais conhecido como Ranchinho, é marcada pela habilidade narrativa de seu pincel. Suas três mil obras (algumas executadas com tinta a base de guache, outras com tinta acrílica e técnicas mistas) podem ser divididas, basicamente, em três categorias: pinturas que apresentam o "hoje" (a cidade e o meio rural na condição em que se encontram contemporaneamente à sua pintura); pinturas em que elementos imaginários misturam-se à realidade vivida ou percebida pelo pintor (sapos, cobras e lagartos enormes em meio à vegetação, por exemplo) e aquelas que apresentam o passado (da cidade e, particularmente, a vida caipira) transfigurado; é esta última que nos interessa, aqui, abordar.

\footnotetext{
* Professora Doutora do Departamento de Arte Visual e do Programa de Pós-Graduação em Letras da Universidade Estadual de Londrina. E-mail: marta_dantas@hotmail.com
} 


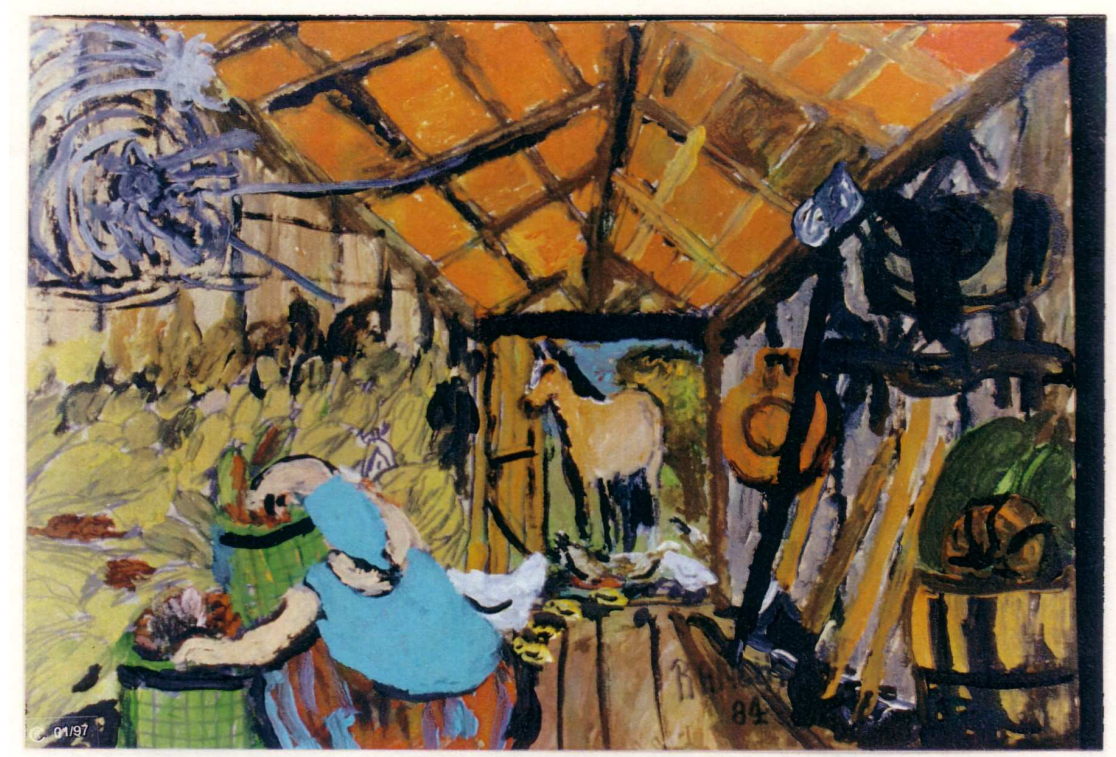

Fig.1 Ranchinho (1984; guache e hidrocor sobre papel cartão; 35x50 cm). ${ }^{1}$

Longe de ser reduzida a um simples momento do fluxo temporal, a pintura de Ranchinho, que celebra o passado, é capaz, ela mesma, de produzir histórias. Muitos de seus quadros "contam" sobre a precariedade das instalações da casa caipira, ao mostrar que ela se limita a um abrigo e que parte das atividades domésticas e do próprio conforto ocorrem no seu exterior. Outros "narram" sobre o conjunto que podemos chamar de habitação rústica: o paiol, o forno de barro, o poço, a moenda, o monjolo. A dimensão utilitária da narração está presente em quadros que mostram a maneira de armazenar o excedente da produção, o milho, por exemplo, no paiol (Fig.1); a maneira como funciona o monjolo e a moenda, ambos acionados pelo aproveitamento da força motriz animal do cavalo; a maneira como se fabrica utensílios com matérias-primas oferecidas pela natureza, como os balaios de palha, os pilões feitos de grandes tocos de madeira, e outros feitos a partir do reaproveitamento do lixo industrial, como as canecas feitas de latas vazias de óleo de cozinha. Muitas de suas imagens 'falam' sobre a divisão do trabalho entre homens, mulheres e crianças. A presença feminina e suas atividades - lavar, cozinhar, costurar, socar grãos no pilão, confeccionar o artesanato, fechar pequenos negócios (como a venda de ovos) com os armazéns da redondeza - é constante; a ênfase está no papel que a mulher desempenha na economia de subsistência. Cabe às crianças, sobretudo às do sexo feminino, ajudar na lida da casa e cuidar dos irmãos menores. Podemos conhecer, também, a dimensão do tempo na cultura caipira, tempo dilatado, que passa lentamente. O tempo do trabalho é marcado pelas estações do ano e pela

\footnotetext{
${ }^{1}$ Foto de Nathany Andrea W. Belmaia, orientanda da autora. Coleção particular. s.d..
} 
duração da luz do dia; o do ócio, pelo dedilhar uma moda de viola (Fig.2), pela voz que conta 'causos' no ritmo da mão que corta o fumo; o tempo do lazer e da sociabilidade manifesta-se nas festas juninas, nos bailes e em outras atividades desenvolvidas no bairro rural; tempo mensurado pelo calendário dos dias dos santos. Muitos quadros dão a conhecer a especificidade da alimentação caipira. Outros, detalhes do interior das vendas, ou armazéns, que, junto com a igrejinha, compõem o cenário do bairro rural. Instrumentos de trabalho, enxadas, machados, carros de boi ocupam o espaço bidimensional das suas telas. Enfim, o que encontramos são imagens que 'falam' sobre a abundância, o ritmo do trabalho, os casamentos e as quermesses, uma verdadeira celebração da vida e das condições que regem uma cultura baseada na subsistência e na troca e que está em vias de desaparecimento: a cultura caipira ${ }^{2}$.

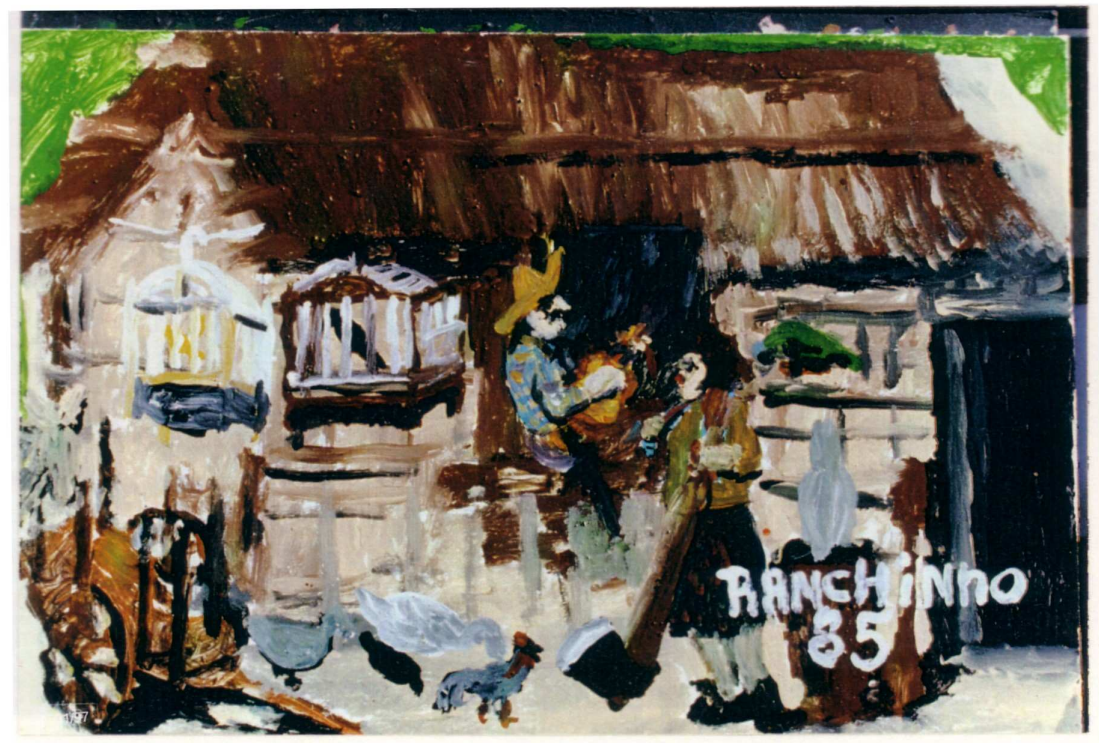

Fig.2 Ranchinho (1985; tinta acrílica sobre eucatex revestido de algodão; 40x60 cm) ${ }^{3}$

Segundo BENJAMIN (1994), a arte de narrar foi tecida há muitos anos em torno das mais antigas formas de trabalho manual. Ela está intimamente ligada à possibilidade de intercambiar experiências ${ }^{4}$, ou seja, contar histórias "sempre foi a arte de contá-las de novo"

\footnotetext{
${ }^{2}$ Segundo Antonio Candido (1987), podemos encontrar a presença da cultura caipira tanto nos grandes proprietários de terra como nos pequenos proprietários e sitiantes, cultivadores instáveis, posseiros e agregados; contudo é nesta segunda categoria que encontramos suas manifestações mais típicas, que definem plenamente a economia caipira de subsistência e a vida caracterizada pela sociabilidade do bairro rural. Ele também esclarece que "ser caipira" é diferente de "ser rural". O "ser rural" indica localização, enquanto que o "ser caipira" referese a um modo de vida, com valores e costumes próprios de uma cultura.

${ }^{3}$ As ilustrações foram fotografadas pela própria autora, in-loco.

4 "Experiência" ("Erfahrung") é um conceito benjaminiano, que significa a experiência no sentido amplo do termo, ou seja, aquela ligada a uma tradição viva e coletiva; ele ocupa um lugar central na obra de Walter Benjamin, tem origem no modelo proustiano de narração e se diferencia de "vivência" ("Erlebnis"), que significa a experiência do indivíduo isolado em seu trabalho e em sua história pessoal.
} 
(BENJAMIN, 1994, p.205). As histórias contadas oralmente por tantos narradores é a fonte a que recorre qualquer narrador tradicional. Entre os tipos mais arcaicos de narradores, encontramos aquele que provém do trabalho sedentário do homem do campo. A imobilidade o conduz ao conhecimento da região, de seus aspectos geográficos, do comportamento da natureza, da cultura e das tradições locais. Ranchinho foi um representante deste tipo arcaico de narrador.

Ele nasceu em 1923, em uma fazenda situada na região de Assis, interior do Estado de São Paulo, no seio de uma família cuja história está inserida na da própria cultura rústica no Brasil ou, se preferirmos, na da cultura caipira, pois ela fez parte da formação da camada de cultivadores que, segundo CANDIDO (1987, p.81), vivia, "muitas vezes à mercê dos bruscos deslocamentos, devido à posse irregular da terra" ou "dependendo do bel-prazer dos latifundiários para prosseguir na faina", e que se organiza em torno da economia de subsistência e da sociabilidade promovida pelo bairro rural. Em 1926, com a morte do pai, a família de Ranchinho mudou-se para a cidade de Assis, o que ocasionou a dispersão e seus membros e a sua proletarização. Na perspectiva do estudo de CANDIDO (1987, p.218), a família ou o indivíduo caipira, diante da civilização urbana, tende a três tipos de reações: “1) aceitação dos traços impostos e propostos; 2) aceitação apenas dos traços impostos; 3) rejeição de ambos." A família de Ranchinho teria aceito os aspectos impostos, "ou seja, um novo ritmo de trabalho, outras relações ecológicas e a aquisição de bens manufaturados, o que não quer dizer que tenha se integrado à cultura urbana" e admitido "somente aqueles caracteres propostos que se apresentavam de forma incoercível como, por exemplo, a racionalização do orçamento, mas manteve suas crenças, sua cultura oral, a valorização do lazer, o respeito ao calendário estabelecido pela Igreja, os conhecimentos sobre a medicina caseira, a dieta tradicional, etc" (DANTAS, 1997, p.19-20).

Embora tenha se fixado na cidade ainda criança, devemos lembrar que, durante boa parte do século XX, a distinção entre campo e cidade, no oeste paulista, era muito branda. É o caso da cidade de Assis e de seu entorno rural. Em larga medida, o campo sofreu transformações mais radicais do que a cidade com a substituição das lavouras pela plantação de cana-de-açúcar destinada a abastecer as usinas de álcool e açúcar e, conseqüentemente, com o fim da economia de subsistência e a substituição do trabalhador que arrendava a terra para o trabalhador sazonal assalariado, o bóia-fria. Mudanças estas que contribuíram para a crise da cultura caipira no oeste paulista.

A vida de Ranchinho foi marcada pelas mudanças que comprometeram a manutenção da cultura caipira. Seu apelido, "Ranchinho", revela muito sobre a sua forma de vida e sobre o 
universo da sua pintura. "Rancho" é o nome atribuído pelo próprio caipira para designar o caráter, muitas vezes, provisório de sua habitação, um lugar destinado ao mero pouso. Por volta de 1959, sem perspectiva de emprego, sem se adaptar à disciplina do trabalho, Ranchinho passou a instalar-se em ranchos abandonados ou construídos por ele mesmo com materiais precários e a perambular pelas ruas da cidade, com uma carriola, a recolher papéis, ferros-velho e garrafas para vendê-los. Ficou logo conhecido por morar em ranchos na beira da estrada, daí a origem de seu apelido, por se exibir sexualmente e, mais tarde, por ser artista marginal. Em larga medida, sua marginalidade é conseqüência dos desajustamentos sofridos pela cultura da qual ele foi um representante.

Não sabemos quando sua atividade criadora teve início, mas temos notícias de que, aos 22 anos, o ato de desenhar já desempenhava papel importante na sua vida. Com material recolhido nas ruas da cidade, papéis de segunda mão, tocos de lápis, ou presenteado por algumas poucas pessoas de seu convívio, Ranchinho ocupava parte de seu tempo desenhando. Desde a década de 50 do século passado, perambulava pela cidade com uma maleta repleta de papéis surrados e canetas hidrocores, material pronto para ser sacado a qualquer momento em que um fato, uma coisa ou uma pessoa merecesse ser, por sua mão, registrado. Nos anos 70, o corretor de imóveis e também colecionador, estudioso autodidata da arte nä̈ve $e^{5}$ fundador do Museu de Arte Primitiva de Assis, Sr. Nazareno Mimessi, passou a incentivá-lo a pintar com tinta a base de guache sobre papelão e organizou exposições dos trabalhos de Ranchinho, apresentando à sociedade assisense uma outra faceta deste homem marginal: a de artista.

A biografia de Ranchinho, escrita por Mimessi ${ }^{6}$, revela uma infância marcada por uma saúde frágil e debilitada. Ele demorou para dar os seus primeiros passos e para falar as primeiras palavras; não aprendeu a ler e a escrever, o que comprometeu mais ainda a sua comunicação verbal, pois sua fala nunca foi além de um murmúrio quase incompreensível. Embora a criação artística não necessite de uma causa primeira, a expressão gráfica de

\footnotetext{
${ }^{5}$ A arte nä̈ve está ligada à descoberta e à valorização da obra de Henri Rousseau, um funcionário da alfândega de Paris que pintava, embora não possuísse nenhuma instrução para tanto e nem participação na instituição arte. As origens históricas da arte naïve datam do final do século XIX e início do XX e estão, indiscutivelmente, ligadas à emergência de novas correntes da arte moderna. Apollinaire, Picasso, André Salomon, Wilhelm Uhde, Max Jacob são alguns dos nomes ligados à sua "descoberta" e repercussão; Anatole Jakovsky, Oto BihaljiMerin, Albert Dasnoy e Raymond Nacenta foram alguns dos responsáveis pela produção do pensamento crítico sobre esta "nova" arte. A arte naïve foi considerada, por alguns críticos, como defensora dos valores tradicionais, como "um sopro de ar fresco em um mundo excessivamente industrializado onde o homem parece rejeitado" (SCHAETTEL, 1994, p.4). Cardinal (1994, p.34) interpreta o surgimento da arte naïve como uma reação contra a angústia da ruptura e da desorientação experimentada pelo homem do povo num período histórico em que ele não podia mais canalizar seus impulsos criativos pelas vias tradicionais, uma arte "entre uma cultura perdida e uma cultura impossível a achar" (PIERRE apud CARDINAL, 1994, p.34).

${ }^{6} \mathrm{O}$ interesse pela vida e obra de Ranchinho levou-o a escrever, em 1978, sua biografia; esta nunca foi publicada.
} 
Ranchinho parece ter, em larga medida, compensado a inabilidade da sua expressão oral. Todavia, não podemos deduzir que os seus desenhos e pinturas sejam meros substitutos da expressão oral. Entre as várias funções que a arte ocidental já teve ao longo da História, a de narrar através de imagens, que perdura por muito tempo, foi muito importante e conheceu sua crise somente no século XIX, com o advento da arte moderna. Entretanto, foram os próprios modernistas que reconheceram e legitimaram como 'arte' a obra de pintores como Ranchinho, nascida às margens da instituição arte ${ }^{7}$. Artistas desse tipo foram batizados com vários nomes: pintores do coração sagrado; pintores da semana dos sete domingos; mestres populares da realidade; pintores de instinto; primitivos modernos; pintores naïfs ou, ainda, adeptos da arte ínsita; da arte imediata; da arte naïve; nomenclaturas sempre problemáticas porque tentam submeter a um denominador comum uma produção artística estritamente individual. Pintor naïf ou arte naïve, nome sugerido por Alfred Jarry, é o mais usual. Naïf ou naïve, vocábulo francês, pode ser traduzido tanto por 'ingênuo(a)' quanto 'primitivo(a)' e, portanto, tende a expressar certo parentesco com a arte de outros períodos - a arte primitiva e a arte primitiva cristã - que desprezavam a representação naturalista do mundo e valorizavam a função narrativa em detrimento da mimética. Todavia, as obras nä̈ves não são produto de um estado preciso da evolução cultural, não são regidas por nenhum cânone, não apresentam uma função social dentro de suas culturas particulares, como ocorre com a arte primitiva e a arte primitiva cristã; pelo contrário, este neoprimitivismo repousa sobre o individualismo. Os naïfs nascem, freqüentemente, das camadas mais humildes da sociedade e descendem de um tipo de profissional, o artesão (Cf. SCHAESTTEL, 1994), embora, quase sempre, sua obra resulte de uma prática solitária. O que gostaríamos de ressaltar é que o caráter narrativo da pintura de Ranchinho e sua estreita relação com a própria experiência de vida do pintor são características encontradas em outros naïfs, entre eles, os camponeses da Croácia (quando esta ainda pertencia a antiga Iugoslávia), como observa Bihalji-Merin:

Para compreender um artista basta, geralmente, penetrar em sua obra; mas com os pintorescamponeses das vilas iugoslavas, vida e obra se confundem e não podem ser concebidas separadamente. São suas atividades que fornecem os temas: suas aflições e suas festas, os batismos, casamentos e enterros, o calendário e suas revoltas, sua devoção a tudo o que a terra oferece. Também sua linguagem é toda rude e áspera, de rústica malícia, de poesia instintiva. (BIHALJI-MERIN, 1972, p.113)

A vida e a obra de Ranchinho apontam-nos na direção de um indivíduo cuja cultura é alicerçada na cultura caipira, na tradição oral e na economia de subsistência. Embora a

\footnotetext{
7 A "instituição arte" compreende tanto o aparelho de produção e distribuição da arte quanto as idéias dominantes sobre uma determinada época (Cf. BÜRGER, 1993, p.52).
} 
singularidade de sua pintura se apresente no seu aspecto rústico, na expressividade de seu traço, na gama de cores da sua palheta, no emplastramento da tinta sobre a tela, enfim, nas suas qualidades pictóricas, e tenha sido atividade solitária e exigência individual, o que está nela narrado são histórias familiares a alguns grupos, porque pertencem ao arsenal de histórias sobre a cultura caipira, que não são de autoria individual, mas representação coletiva reproduzida por tantos narradores e legitimada por tantos ouvintes que nelas se identificam e que delas compartilham. Suas pinturas são reminiscências de uma cultura, de uma identidade cultural transmitida oralmente; elas são fruto do trabalho da memória.

Não tomamos a memória na concepção bergsoniana, ou seja, como restrita ao corpo e ao espírito de um indivíduo (Cf. BOSI, 1987, p.54), mas como uma faculdade relacionada com os grupos sociais de convívio e referência do indivíduo, tal como explica HALBWACHS $(1990)^{8}$, pois as obras de Ranchinho narram histórias que não são oriundas, exclusivamente, de sua experiência individual, mas da repetição transfigurada de histórias e experiências alheias. Não significa que a memória individual do pintor se reduza à coletiva, mas, como afirma DUVIGNAUD (apud HALBWACHS, 1990, p.17), ela nasce da "trama coletiva da existência". Podemos dizer que aquilo que emergiu da memória individual do pintor é um ponto de vista da memória coletiva, dos grupos pertencentes à cultura caipira.

O ponto de vista do pintor em relação ao passado é utópico. Ranchinho apresenta, em seus quadros, imagens idealizadas da cultura caipira. Sabemos que dentro dos moldes da cultura rústica, morrer de maleita, de fome ou vítima da violência, era comum. Sabemos, também, que os recursos eram poucos, que a vida era precária e implicava em muitas restrições, particularmente, de alimentos como a carne vermelha, o leite e o pão. Mas as imagens da cultura caipira pintadas por Ranchinho nos apresentam uma vida harmoniosa, feliz e ausente de conflitos.

A memória é vida. Ela está aberta à dialética da lembrança e do esquecimento; um fenômeno sempre atual porque liga o vivido ao eterno presente. Sua verdadeira missão é destruir a História - operação intelectual e laicizante que exige a análise e o discurso crítico é rechaçá-la, como explica NORA (apud DECCA, 1992, p.130). As reminiscências do passado não são as mesmas que Ranchinho experimentou na infância, pois o "simples fato de lembrar o passado, no presente, exclui a identidade entre as imagens de um e de outro" (BOSI, 1987, p.55). Assim, a memória salva o passado no presente, transforma o passado lembrado porque este assume, à luz do presente, uma nova forma. O presente também se

\footnotetext{
${ }^{8}$ Não é objetivo deste artigo discorrer sobre a memória e suas várias abordagens, mas sobre a relação dela com a pintura de Ranchinho e, para tanto, optamos por uma abordagem mais social.
} 
transforma, porque este se revela como realização possível dessa promessa anterior. Nessa perspectiva, a negação dos infortúnios do modo de vida caipira, nas imagens produzidas por Ranchinho, representa "a necessidade de criar imagens de 'outra' realidade possível" (MARCUSE, 1986, p.63), uma "utopia retrospectiva". Ranchinho construiu um novo sentido para o que viveu e ouviu sobre o passado e os atualizou cumprindo, assim, com uma das funções que o narrador desempenha na cultura oral. Podemos dizer que a sua "utopia retrospectiva" é fruto do trabalho de transfiguração da realidade, a partir de experiências suas e alheias.

A "utopia retrospectiva" de Ranchinho é a atualização de um arquétipo ${ }^{10}$ : o da "idade do ouro". Ao atualizar este arquétipo, o pintor coloca-se como um representante da tradição oral, pois esta "não se constitui, essencialmente, pelo repertório de histórias formado ao longo dos tempos, mas pela contínua atualização destas histórias, o que requer ininterruptas (re)criações de conteúdos a cada contexto" (FERNANDES, 2007, p.49). Sua "utopia retrospectiva" deve ser compreendida neste contexto de crise da cultura caipira. Ao atualizar o arquétipo da "idade do ouro", sua pintura incorpora a voz de uma certa coletividade, porque compartilha com ela o sentimento de inadequação e de incerteza. O estudo de CANDIDO (1987) revela que a valorização idealizada do passado é constante nas vozes daqueles que se viram diante da crise da cultura caipira, numa situação entre o sitiante e o assalariado, entre a manutenção da tradição e sua mudança:

Nas palavras do caipira [...] o 'tempo de dante', ou 'dos antigos', era o próprio reino da fartura. Conforme um deles, no tempo do avô de seu pai, a medida para semear não era o alqueire, mas o dedal... Um dedal cheio de arroz dava produção abundante [...] (CANDIDO, 1987, p.194).

A busca de uma realidade inexistente ou, como diz ADORNO (1982, p.46), a busca do "novo" é a nostalgia daquilo que já existiu e, na arte, ela traz consigo a imagem da decadência:

Pela recusa intransigente da aparência de reconciliação, a arte mantém a utopia no seio do irreconciliado, consciência autêntica de uma época, em que a possibilidade real da utopia [...] se conjuga num ponto extremo com a possibilidade de catástrofe total. (ADORNO, 1982, p.46)

\footnotetext{
${ }^{9}$ Entendemos por utopia "aquelas idéias, representações e teorias que aspiram a uma outra realidade, uma realidade inexistente" (LÖWY, 1991, p.13). "Utopia retrospectiva” é um termo utilizado por Antonio Candido (1987, p.193) para designar um saudosismo transfigurador que, segundo ele, manifesta-se nos indivíduos que tiveram contato com a vida tradicional e puderam compará-la com as condições de vida modernas. Este saudosismo diz respeito, principalmente, a três tópicos: abundância, solidariedade e sabedoria.

${ }^{10}$ Baseado no conceito de arquétipo de Paul Zumthor, Frederico Fernandes (2007, p.50) explica: “Arquétipo é uma categoria criada para classificar o texto em estado latente", ele "caracteriza-se como uma espécie de texto virtual, que preexiste ao texto materializado".
} 
Nas imagens de Ranchinho, bem como na voz de outros narradores de sua linhagem, a "catástrofe total" é o fim de uma cultura na qual os caipiras tinham razão de ser.

\section{A narradora trapeira}

Diante das obras de Ranchinho, a inabilidade do traço, a perspectiva capenga, a rusticidade da tinta espalhada sobre a tela e a alegria de viver que emana de suas histórias despertam em nós uma emoção semelhante àquela que experimentamos diante dos desenhos infantis. Mas quando nos deparamos com a obra plástica de Efigênia Rolim, conhecida como Rainha do Papel, a recepção é bem outra. Enquanto o naïf utiliza-se de materiais e suportes tradicionais (tinta sobre tela), esta artista bruta ${ }^{11}$ lança mão dos materiais que encontra ao seu redor para criar objetos distantes das belas artes e próximos da bricolage $^{12}$, e nossa atitude diante deles é, na maioria das vezes, de rejeição. Estes objetos, feitos com restos de tecidos, papéis, plásticos e outros detritos, constituem o aparato necessário para a performance da narradora, pois a narração não é produto exclusivo da voz; o corpo "engaja-se à voz, com movimento de membros e tronco, com expressões faciais" (FERNANDES, 2007, p.325-326) e intervém com seus gestos na construção dos sentidos.

Natural de Abre Campo, interior de Minas Gerais, Efigênia Ramos Rolim nasceu em 1931. Sua história de vida não é muito diferente da de Ranchinho. Filha de lavrador, cresceu e viveu durante muito tempo no campo em Minas Gerais e, posteriormente, no Paraná. Casouse, teve nove filhos e, em 1971, devido à delicada saúde do marido, mudou-se com a sua família para a cidade de Curitiba, onde passou por muitas privações, chegando a praticar a mendicância. Como tantos outros artistas brutos, o "espírito da arte", palavras da própria Efigênia, manifestou-se quando já tinha idade avançada, depois de uma experiência 'traumática', a morte do marido, em 1988, que a deixou só para enfrentar a vida na grande cidade e cuidar dos filhos: "naquele momento deu uma explosão, e eu chorei; parece que meu corpo se despedaçou [...] A arte nasceu naquela hora" (ROLIM apud OLIVEIRA; DODEBEI, 2007, p.9). Em 1990, assumiu o seu 'lado' poetiza e começou a apresentar seus

\footnotetext{
${ }^{11}$ O termo "arte bruta" foi criado pelo artista plástico francês Jean Dubuffet, em 1945 para designar "as obras executadas por pessoas imunes à cultura artística, da qual o mimetismo [...] tem pouca ou nenhuma contribuição, pois seus autores tiram tudo (temas, materiais para colocar na obra, meios de transposição, ritmos, fragmentos de escrituras, etc.) de sua profundeza e não dos cânones da arte clássica ou da arte que está em moda. Nós assistimos à operação artística toda pura, bruta, reinventada no interior de todas as suas fases por seu autor, a partir somente de seus próprios impulsos” (DUBUFFET, 1986, p.201-202).

${ }^{12}$ A bricolage é o modus operandi do bricoleur. O bricoleur é aquele que cria coisas úteis a partir de resíduos, retos produzidos pelo e no grupo em que vive (Cf. LÉVI-STRAUSS, 1970, p.37-43).
} 
livros de poesia na Feira do Poeta, no centro de Curitiba. Na mesma época, passou a "dar vida aos míseros caídos, o que perdeu o recheio, que perdeu o sabor" (palavras da própria Efigênia), aos restos e às coisas que, como ela, não possuíam mais uma função na sociedade. Cumprir a missão revelada pelo "espírito da arte" — "dar vida aos míseros caídos" — passou a ser a razão de sua vida. Quanto questionada sobre a sua infância, Efigênia explica que cresceu escutando as histórias que seu pai contava, histórias que a encantavam e das quais jamais se esqueceu, indicando seu pertencimento à tradição oral. Para ela, criar é uma espécie de missão ordenada pelo poder superior, álibi comum a muitos artistas brutos e que deve ser compreendido no contexto de uma sociedade em que 'ser artista' é um privilégio de poucos. Efigência admite que a criação dos seus objetos nasceu da necessidade de sustentar "de cem maneiras o fluxo do que é dito" (BENJAMIN, 1994, p.221). Segundo ela, numa entrevista concedida em 2005, uma velha a recitar poesias no meio da rua seria, sem dúvida, motivo para zombarias e desprezo; os objetos “justificariam” e auxiliariam a sua performance. Passou, então, a recitar suas poesias nas ruas, trajada com roupas, acessórios e acompanhada de outros objetos, tudo feito de restos, de lixo (Fig.3). Este comportamento é tido por muitos como loucura, mas, sobre isso, Efigênia explica:

É um pouquinho de loucura que está dentro de mim,/ Eu vou mostrar para as criaturas que a vida é sempre assim. / Eu não tenho muita cultura para seguir esse caminho, mas nas minhas aventuras sei que não estou sozinho. /Não sei pra onde eu vou, e ninguém sabe da onde eu vim, mas se Deus me convidou eu fico até o fim. / Mas pelas ruas isoladas ninguém me conhecia, mas eu sentava nas calçadas e declamava poesia. [...] Com meu chapéu na cabeça é muito pouco, espero que o mundo reconheça quais são os loucos. / Eu fiz a minha roupa com tanto capricho, me chamam de louca porque visto lixo./ $\mathrm{E}$ as crianças que me chamam de bruxinha, / $\hat{o}$ pobre sem defesa, que defende a natureza, me chama de madrinha... ${ }^{13}$

E zomba daqueles que acreditam na normalidade: "Somos páginas fechadas/ que devem ser abertas/ mesmo as coisas erradas/ muitos dizem que estão certas" (http://www.artcanal.com.br/oscardambrosio/efigeniarolim.htm).

\footnotetext{
${ }^{13}$ Esta poesia é frequentemente recitada por Efigênia e foi registrada em áudio em 2006 e constitui parte do material colhido e analisado para o projeto de pesquisa "Infames, casos de singularidade histórica".
} 


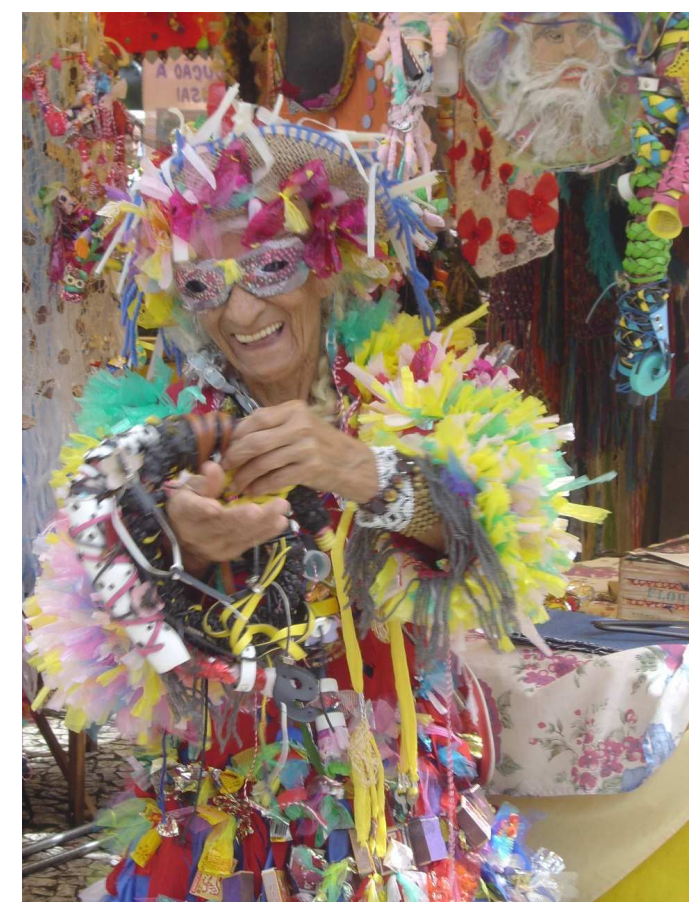

Fig.3 Efigênia em ação (Feira do Largo da Ordem, Curitiba, 2006)

Enquanto Ranchinho é o narrador enraizado, ligado ao campo, Efigênia é o seu inverso, o narrador desenraizado. O desenraizamento está ligado à cidade, este lugar onde tudo e todos estão de passagem, lugar de muitos cruzamentos, de encontros de gente de hábitos, costumes, língua e religião diferentes, "berço daquilo que os sociólogos, a partir da obra de Tönnies, chamam de Gesellschaf, 'sociedade', em oposição ao que chamam de Gemeinschaft, "comunidade"” (CÍCERO, 2005, p.15). Embora tenha vivido parte de sua vida no campo, Efigênia coloca-se como cidadã da pólis e chama para si a responsabilidade do social, particularmente das questões relacionadas aos problemas ecológicos.

No caso de Ranchinho, a narrativa prepondera sobre o próprio narrador, enquanto que no da Efigênia, a atenção recai sobre o papel do narrador, porque a "narrativa numa performance corresponde a um texto em construção" (FERNANDES, 2007, p.312). Seu sentido ocorre sempre na tensão entre o narrador e o público, aquele que ouve.

Segundo Fernandes, o narrador

desempenha uma tripla função na cultura oral: narra, é o performer sensível ao auditório, já que incorpora a voz da comunidade; ouve, troca experiências com outros narradores e absorve as histórias que lhe contam; e cria, torna-se o responsável por construir um sentido para o que ouviu, bem como por atualizar isso com significantes e significados diferenciados. (FERNANDES, 2007, p.56)

Sua autoridade é legitimada pela comunidade que o aceita como narrador, que o toma como seu porta voz. Mas como é possível que esta tripla função do narrador funcione no 
contexto de uma cidade grande? Em meio a uma sociedade, a que comunidade se dirige o discurso de Efigênia? Neste caso, mais do que nunca a performance acontece numa situação de tensão entre o narrador e os seus ouvintes, pois a narradora não só desconhece a reação do auditório, mas o próprio auditório, porque este não é um grupo com um perfil determinado, mas o cruzamento de gente de todos os tipos. Mais do que nunca, a situação parece exigir da narradora certa flexibilidade, "saber o quê e onde falar, ou melhor, falar no momento certo" (FERNANDES, 2007, p.317), para falar com autoridade. Se Efigênia não incorpora a voz de uma comunidade, quais vozes ela ouve? No limite, podemos questionar se trata-se, realmente, de uma narradora. A resposta é afirmativa, mas Efigênia não é uma narradora tradicional.

\section{Segundo Cícero,}

a poesia desenraizada surge quando a escrita põe à disposição do leitor as mais diversas instâncias dos mais diferentes poemas [...] dá-se ao leitor a possibilidade de escolher entre inúmeros poemas que contam diferentes mitos que contradizem uns aos outros [...] ele escolherá a constelação dos poemas que irão compor a sua antologia absolutamente pessoal. (CÍCERO, 2005, p.17)

Ao citar este autor, pretende-se enfatizar uma idéia, a de que o desenraizamento implica na possibilidade de escolha do que se lê e, acrescentaríamos também, na escolha do que se ouve, permitindo, a uma narradora como Efigênia, escolher, entre tudo o que lê e ouve, aquilo que julga representar melhor os seus anseios e os das inúmeras pessoas diferentes que compõem a sociedade. A escolha de Efigênia revela sua sensibilidade e sua sabedoria. É, sobretudo, por meio de um problema candente — o do meio ambiente — veiculado em todas as mídias e que atinge a todos indistintamente, que ela busca expressar os anseios da sociedade e legitimar sua voz. Mas nos enganamos ao achar que "problemas ecológicos" seja um tema absolutamente atual. Textos produzidos no final do século XIX por críticos da modernidade, como o historiador da arte John Ruskin, já denunciavam, entre outras coisas, o desmatamento das florestas inglesas em virtude da expansão das estradas de ferro e a água contaminada pelos resíduos químicos das indústrias têxteis. No universo da cultura caipira, os problemas com o meio ambiente e os conselhos práticos para a sua atenuação surgem a partir de um contexto em que o ajustamento dos grupos caipiras, dado por uma espécie de continuidade entre homem e natureza com o meio total e imediato, modifica-se, ou seja, a partir do momento em que o meio deixa de representar, para o grupo, uma totalidade "cujos limites coincidiam com os limites da atividade e da mobilidade grupais" (CANDIDO, 1987, p.173) e passa a ser substituído pelo ajustamento a vários meios, mediados e imediatos, devido à valorização das propriedades rurais e sua conseqüente fragmentação e capitalização. 
Assim, o "desequilíbrio nas relações entre o homem e a natureza" é um tema que, de certa forma, faz parte, há algum tempo, do repertório de muitos narradores.

Podemos dizer que as lições de Efigênia sobre o meio ambiente, tanto quanto os seus objetos, são textos nascidos da bricolage, a partir de fragmentos de experiências suas, alheias, de sabedoria popular, mas, também, de informações oriundas dos meios midiáticos (onde, muitas vezes, o discurso científico é massificado, ou, a informação massificada recebe a roupagem de um discurso científico); uma verdadeira antropofagia, onde as representações individuais, locais, de outras pessoas e veiculadas nas mídias são digeridas e ganham novos sentidos. E é neste ponto que entra a importância da sua performance.

Para declamar suas poesias e contar suas histórias, Efigênia traveste-se com roupas e acessórios criados por ela com papéis de bala, restos de couro, plásticos, trapos e farrapos. Ao vê-la, como bem observou WALDECK (2006, p.11), temos a impressão de estar diante de uma assemblage viva. Ela também utiliza seus objetos que, aliás, só fazem sentido nessa relação com o texto oral; muitos deles são personagens de suas histórias e sua função é "ilustrar" e demarcar o tempo, o espaço e a ação na narrativa. Embora haja sempre a possibilidade de improvisação, histórias e personagens repetem-se. O "Doutor Penenem", "médico e guardião da floresta", é um dos seus personagens mais conhecidos, ele aparece em várias histórias e, embora seja sujeito de várias aventuras, a lição a ser extraída é sempre a mesma: o respeito pela natureza. A repetição é um recurso pedagógico e de fixação, mnemônico, portanto. A compreensão da narrativa é reforçada pelos seus gestos, às vezes, exagerados (ela pula, joga-se no chão, por exemplo), pelos vários timbres de sua voz, pelos gritos, sussurros, pelas onomatopéias e pela habilidade de repentista. Todo o seu corpo é mobilizado em prol da construção de sentidos e da ampliação da capacidade de comunicação. Sua performance, como a de outros narradores, apresenta um nível técnico e outro discursivo:

No nível técnico estariam os usos da voz emprestada a personagens, imitações de trejeitos de modo a caricaturar pessoas, a interpretação por gestos, as expressões faciais e outros artifícios técnicos que visam explorar o texto em seu potencial de materialização. No outro nível encontram-se os embates discursivos que interferem no encadeamento das narrativas, a sensibilidade do narrador perante o auditório, as forças que atuam na construção de uma expressão ideológica. (FERNANDES, 2007, p.328)

Todavia, a performance, por si, não bastaria nem autorizaria tratarmos Efigênia como uma narradora. Segundo Fernandes, "todo narrador pode ser um bom performer, mas nem todo performer é um narrador"; ele enfatiza que a diferença entre o narrador e o contador de histórias "assenta-se no fato de que o narrador apresenta um vínculo com a comunidade narrativa e não prioriza a técnica em detrimento do conteúdo" (FERNANDES, 2007, p.329). 
Embora dê uma importância considerável ao espetáculo, Efigênia não é uma atriz, nem a figura intermediária entre um repertório de histórias ou de poesia oral e o público. Sua história de vida apresenta vínculos com a tradição oral - aliás, ela prefere o dinamismo da poesia oral, de fluxo intangível à imobilidade do texto escrito — embora não seja a porta-voz de uma comunidade específica. Sua tarefa é justamente se fazer ouvida, fazer valer sua experiência, reconquistar um papel que, outrora, foi do idoso, o de transmissor de conhecimentos, o de portador das sábias palavras. Ela não se enquadra no estereótipo do idoso melancólico e cabisbaixo, passivo e submisso, nem participa das atividades da 'melhor idade'; ela rejeita todo e qualquer papel imposto ao idoso pela sociedade. Reinventou a vida através da arte, transformou sua velhice em vontade de potência, em força afirmadora da vida e, por isso, não abdica do seu papel de cidadã e procura, através da arte de narrar e transformar o lixo, intervir, com autoridade, na sociedade, ou, como ela mesma diz, "salvar o mundo". É a coerência entre o seu texto oral, em defesa da natureza e contra o consumismo, e sua obra plástica, ou, é na coerência do seu discurso que a sua autoridade foi conquistada. Efigênia não só conquistou um espaço (uma barraca) na feira que ocorre todos os domingos no Largo da Ordem, em Curitiba - onde vende menos seus objetos, mais seus conselhos e, sobretudo, a força com que afirma a vida através da arte - mas conquistou espaço em tantos outros lugares, onde sua voz pôde ser ouvida com efeito amplificado: no Senado, nas comemorações dos 500 anos do Brasil; no Fórum Mundial de 2003, em Porto Alegre. É o reconhecimento da sua autoridade como narradora que tornou a sua presença indispensável em eventos como o Projeto Fera (Festival de Arte da Rede Estudantil do Paraná), patrocinado pelo Governo do Estado do Paraná, onde ministra oficinas, e o Simpósio Internacional de Contadores de Histórias.

Efigênia, ao transformar o lixo produzido pela sociedade e dar a ele uma função, a de encantar $^{14} \mathrm{o}$ mundo, realiza aquela transfiguração alquímica que, segundo BAUDELAIRE (Cf. COLI, 1988, p.236), cabe somente ao artista moderno fazer: transformar a lama em ouro; lama necessária para que exista o ouro, lama que é, ela própria, produto do homem no mundo. Eis que nos deparamos com um tipo de narradora cujas origens se encontram no século XIX e se confundem com a história da sociedade industrial e da cidade moderna, pois sua matériaprima são os restos de todo tipo de produto do homem no mundo: restos de experiências do próprio artista, restos de experiências alheias, restos de tradições; eis a narradora trapeira. $\mathrm{O}$

\footnotetext{
${ }^{14}$ A expressão "encantar o mundo" refere-se ao processo inverso a aquele que tanto Hegel como Max Weber chamaram de "desencantamento do mundo", ou seja, um processo que teve suas origens na modernidade ou no racionalismo ocidental e que consiste na desintegração das concepções religiosas e na substituição da explicação mitológica pela científica.
} 
que a move é o desejo de que nada se perca e que tudo se transforme pela força das palavras e pelo trabalho das mãos. O narrador trapeiro representa, simultaneamente, a crise e a perpetuação do narrador tradicional; ele é o representante da tradição oral em frangalhos em uma sociedade onde não há mais lugar para o sujeito experiente e nem para a experiência, numa época em que "passou o tempo em que o tempo não contava" (VALÉRY apud BENJAMIN, 1994, p.206) e que não se cultiva “o que não pode ser abreviado" (VALÉRY apud BENJAMIN, 1994, p.206).

Enquanto os olhos de Ranchinho fixavam-se, sobretudo, no passado, o eco da voz de Efigênia que ser ouvido no futuro. Muita coisa há em comum entre estes narradores: a origem humilde, suas histórias de vida... uma certa relação com os restos produzidos pelo homem Ranchinho foi catador de lixo, Efigênia amadrinha o lixo - e a capacidade de transfigurá-la. Eles são a prova de que o narrador tradicional não morreu, transformou-se e vive nesta situação ambígua entre a experiência e a vivência, entre ser o guardião da tradição e o seu transformador.

\section{Referências}

ADORNO, Theodor W. Teoria estética. Trad. Artur Morão. São Paulo: Martins Fontes, 1982.

BENJAMIN, Walter. O narrador. Considerações sobre a obra de Nikolai Leskov. In: Magia e técnica, arte e política. Trad. Sérgio Paulo Rouanet. 7. ed.. São Paulo: Brasiliense, 1994, v. 1, p. 197-221.

BIHALJI-MERIN, Oto. Les maîtres de l'art naïf. Bruxelles: La Connaissance, 1972.

BOSI, Ecléa. Memória e sociedade: lembranças de velhos. São Paulo: EDUSP, 1987.

BÜRGER, Peter. Teoria da vanguarda. Lisboa: Vega, 1993.

CANDIDO, Antonio. Os parceiros do Rio Bonito. São Paulo: Livraria Duas Cidades, 1987.

CARDINAL, Roger. Regards sur la peinture naïve. In: L'oeuf sauvage. nº, p.32-48, automne, 1994.

CÍCERO, Antonio. Finalidade sem fim. Ensaios sobre poesia e arte. São Paulo: Copanhia das Letras, 2005.

COLI, Jorge. Manet: o enigma do olhar. In: NOVAES, Adauto (org.). O olhar. São Paulo: São Paulo: Companhia das Letras, 1988, p. 225-245. 
D'AMBROSIO, Oscar. A destruidora de limites.

Disponível em: http://www.artcanal.com.br/oscardambrosio/efigeniarolim.htm Acesso em 01 de março, 2008.

DANTAS, Marta. De olho no passado: a pintura de Ranchinho. 1997. 120 fs. Dissertação (Mestrado em História) — UNESP, Campus de Assis/SP, 1997.

DECCA, Edgar S. de. Memória e cidadania. In: CUNHA, M. C. P. (org.). O direito à memória: patrimônio histórico e cidadania. São Paulo: Departamento do Patrimônio Histórico, 1992, p.129-136.

DUBUFFET, Jean. Prospectus et tous écrits suivants. Paris: Gallimard, 1986.

FERNANDES, Frederico. A voz e o sentido: poesia oral em sincronia. São Paulo: Editora UNESP, 2007.

HALBWACHS, Maurice. A memória coletiva. Trad. Laurent L. Schaffter. São Paulo: Vértice e Editora da Revista dos Tribunais, 1990.

LÉVI-STRAUSS, Claude. O pensamento selvagem. Trad. Maria Celeste da Costa e Souza e Almir de O. Aguiar. São Paulo: Nacional, 1970.

LÖWY, Michel. Redenção e utopia: o judaísmo libertário na Europa Central. Trad. Paulo Neves. São Paulo: Companhia das Letras, 1989.

MARCUSE, Herbert. A dimensão estética. Edições 70, 1986.

MIMESSI, José Nazareno. Ranchinho, o pintor primitivo de Assis. (mimeo). Assis, 1978.

OLIVEIRA; Vânia de; DODEBEI; Vera. [s.d.] Patrimonialização e musealização: a arte efêmera de Efigênia Rolim e Hélio Leites. $31^{\circ}$ Encontro Anual da ANPOCS, Caxambu, MG, 2007. Disponível em:

http://201.48.149.89/anpocs/arquivos/10_10_2007_17_34_40.pdf

Acesso em 01 de março, 2008.

SCHAETTEL, Charles. L'art naïf. Paris: Presses Universitaires de France, 1994.

WALDECK, Guacira. Efigênia Rolim e Hélio Leites: a vida das coisas. Rio de Janeiro: IPHAN, CNFCP, 2006, p. 11. Catálogo da exposição. 